\title{
PENTINGNYA PENDIDIKAN KARAKTER PADA SISWA TINGKAT SEKOLAH DASAR DI ZAMAN SERBA DIGITAL
}

\author{
HALAWATI \\ 17210008 \\ STAI DDI KOTA MAKASSAR \\ halawatihalwa99@gmail.com
}

\begin{abstract}
Abstrak
Pendidikan karakter adalah sebuah usaha untuk menerapkan nilai-nilai agama, moral, etika pada peserta didik melalui ilmu pengetahuan, dibantu oleh orang tua, guru, serta masyarakat yang sangat penting dalam pembentukan dan perkembangan karakter peserta didik.Setiap anak memiliki potensi yang baik sejak lahir, namun potensi tersebut harus terus diasah dan disosialisasikan dengan baik agar karakter setiap anak terbentuk dan berkembang secara maksimal.Di zaman serba digital ini juga anak dengan mudahnya menggunakan media digital. Zaman digital yang bukan hanya memiliki dampak positif, namun juga dampak negative pun menjadi tugas sendiri bagi pendidik, orang tua dan masyrakat dewasa dalam membimbing dan memantau apa yang anak lakukan dengan media digitalnya tersebut, sehingga anak mampu memanfaatkan media digitalnya sebaik mungkin dan mendapatkan manfaat yang baik untuk dirinya dan hidupnya.
\end{abstract}

\section{A. PENDAHULUAN}

pendidikan adalah usaha sadar dan terencana untuk mewujudkan suasana belajar dan proses pembelajaran agar peserta didik secara aktif mengembangkan potensi dirinya untuk memiliki kekuatan spiritual keagamaan, pengendalian diri, kepribadian, kecerdasan, akhlak mulia, serta keterampilan yang diperlukan dirinya, masyarakat, bangsa dan negara". Ki Hadjar Dewantara dalam Kongres Taman Siswa (1930) mengatakan bahwa pendidikan umumnya berarti daya upaya untuk memajukan bertumbuhnya budi pekerti (kekuatan batin, karakter), pikiran (intelek), dan tubuh anak. Pendidikan adalah usaha sadar dalam proses pembelajaran baik dari segi akademik maupun non-akademik dengan tujuan para peserta didik mampu mengembangkan ilmu pengetahuan, sikap dan perilaku menjadi lebih baik.

Proses pendidikan karakter perlu dilakukan sejak dini dan sudah harus dimaksimalkan pada usia sekolah dasar. Potensi yang baik sebenarnya sudah dimiliki manusia sejak lahir, tetapi potensi tersebut harus terus dibina dan dikembangkan melalui sosialisasi baik dari keluarga, sekolah, maupun masyarakat.

Di era globalisasi ini manusia dengan mudahnya menggunakan teknologi yang ada bukan hanya orang dewasa namun juga anak-anak. Teknologi saat ini digunakan dalam dunia pendidikan karena sangat membantu proses pembelajaran dan pengembangan ilmu pengetahuan. Selain itu, teknologi juga mampu digunakan sebagai alat komunikasi antara pendidik dan peserta didik.Namun, 
bagaimanapun juga teknologi mempunyai dampak positif maupun negatif dalam ranah pendidikan. Banyaknya kasus cyberbullying, tawuran antar pelajar, kekerasan bahan pelecehan seksual pada anak merupakan lemahnya karakter bangsa.Karakter bangsa yang baik harus dibentuk dan dididik sedini mungkin agar masyarakat mampu menanamkan sifat-sifat dan perilaku yang baik sejak dini sehingga dapat menekan angka kriminal pada kasus-kasus di atas.

\section{B. Pengertian Pendidikan Karakter}

Istilah karakter diambil dari bahasa Yunani "Charassian" yang berarti "to mark" atau menandai dan memfokuskan bagaimana mengaplikasikan nilai kebaikan dalam bentuk tindakan atau tingkah laku, sehingga orang yang tidak jujur, kejam, rakus dan perilaku jelek lainnya dikatakan orang berkarakter jelek. Sebaliknya, orang yang perilakunya sesuai dengan kaidah moral disebut dengan berkarakter mulia.Pengertian karakter menurut Pusat Bahasa Depdiknas adalah "bawaan, hati, jiwa, kepribadian, budi pekerti, perilaku, personalitas, sifat, tabiat, temperamen, watak".Adapun berkarakter, adalah berkepribadian, berperilaku, bersifat, dan berwatak.

Sementara untuk pengertian pendidikan karakater Lickona (1992) menyebutkan "character education is the deliberate effort to help people understand, care about, and act upon core ethical values", hal ini berarti bahwa pendidikan karakter adalah upaya yang disengaja untuk membantu orang memahami, peduli, dan bertindak berdasarkan nilai-nilai etika inti. Pendidikan Karakter adalah pendidikan yang mendukung perkembangan sosial, emosional, dan etis siswa. Semantara secara sederhana pendidikan karakter dapat dimaknai sebagai hal postif apa saja yang dilakukan guru dan berpengaruh kepada karakter siswa yang diajarnya (Samani \& Hariyanto, 2013). Pendidikan karakter merupakan sebuah upaya untuk membangun karakter (character building). Elmubarok (2008, p. 102) menyebutkan bahwa character building merupakan proses mengukir atau memahat jiwa sedemikian rupa, sehingga berbentuk unik, menarik, dan berbeda atau dapat dibedakan dengan orang lain, ibarat sebauh huruf dalam alfabeta yang tak pernah sama antara yang satu dengan yang lain, demikianlah orangorang yang berkarakter dapat dibedakan satu dengan yang lainnya. Pendidikan karakter dapat disebut juga sebagai pendidikan moral, pendidikan nilai, pendidikan dunia afektif, pendidikan akhlak, atau pendidikan budi pekerti.

\section{Tujuan Pendidikan Karakter}

Dini (2018) menyatakan bahwa Pendidikan karakter bertujuan agar peserta didik sebagai penerus bangsa mempunyai akhak dan moral yang baik, untuk menciptakan kehiupan berbangsan yang adil, aman dan makmur.Hal ini berkaitan dengan UU nomor 20 Tahun 2003 tentang pendidikan nasional.

Landasan pendidikan karakter disebut di dalam Alqur"ean Q.S 31:17 "Hai anakku, dirikanlah sholat dan suruhlah manusia mengerjakan yang baik dan cegahlah mereka dari perbuatan yang mungkar dan bersabarlah terhadap apa yang menimpa kamu. Sesungguhnya yang demikian itu termasuk hal-hal yang diwajibkan oleh Allah". Al-qur"an menjelaskan dengan tegas agar manusia menyerukan dan menegakkan kebenaran dan menjauhkan perbuatan yang munkar. Pendidikan karakter yang diberikan seorang ayah kepada anaknya untuk selalu mengerjakan sholat, dan selalu bersabar. 
Pemerintah memperkenalkan program pemerintah yang namanya Penguatan Pendidikan Karakter (PPK), PPK merupakan usaha untuk membudayakan pendidikan karakter di sekolah. Program PPK akan dilaksanakan dengan bertahap dan sesuai kebutuhan. Program PPK bertujuan untuk mendorong pendidikan berkualitas dan bermoral yang merata di seluruh bangsa. Penerbitan Peraturan Presiden nomor 87 pasal 2 tahun 2017 tentang Penguatan Pendidikan Karakter (PPK), PPK memiliki tujuan :

1) Membangun dan membekali peserta didik sebagai generasi emas Indonesia tahun 2045 dengan jiwa pancasila dan pendidikan karakter yang baik guna menghadapi dinamika perubahan di masa depan.

2) Mengembangkan platform pendidikan nasional yang meletakkan pendidikan karakter sebagai jiwa utama dalam penyelenggaraan pendidikan bagi peserta didik dengan dukungan pelibatan publik yang dilakukan melalui pendidikan jalur formal, nonformal, dan informal dengan memperhatikan keberagaman budaya indonesia dan

3) Merevitalisasi dan memperkuat potensi dan kompetensi penidik, tenaga kependidikan, peserta didik, masyarakat, dan lingkungan keluarga dalam mengimplementasikan PPK.

Menurut Piaget, anak usia 7 - 11 tahun mengalami tingkat perkembangan Operasinal konkret. Tingkat ini merupakan permulaan berpikir rasional.Ini berarti anak memiliki operasioperasi logis yang dapat diterapkannya pada masalah-masala yang konkret.Bila mengadapi suatu pertentangan antara pikiran dan persepsi, anak dalam periode ini memilih mengambil keputusan logis dan bukan keputusan perseptual seperti anak praoperasional. Pada zaman digital, anak usia sekolah dasar sudah bisa mengoperasikan barang-barang teknologi seperti Ponsel, komputer, video game dan lain-lain.

Teknologi membantu memudahkan segala aktifitas manusia, pencarian informasi, penyampaian informasi. Teknologi secara umum adalah sebuah proses yang meningkatkan nilai tambah, teknologi merupakan produk yang digunakan dan dihasilkan untuk memudahkan dan meningkatkan kinerja, struktur atau sistam di mana proses dan produk itu dikembangkan dan digunakan.

Teknologi bermanfaat sangat besar dalam dunia pendidikan.Pencarian tentang literasiliterasi untuk penambahan ilmu pengetahuan dalam pembelajaran, bisa dimanfaatkan teknologi.Peserta didik bisa menulusuri google atau yahoo dan situs lainnya dalam mencari jurnal, makalah, dan buku elektronik.Meskipun demikian, bukan berarti pembelajaran tidak menggunakan buku paket yang tersedia, penggunaan literasi dari Google atau situs lainnya hanya bertujuan untuk menambah pengetahuan dan bahan dalam proses pembelajaran.

Teknologi bukan hanya memiliki dampak positif namun juga dampak negative. Untuk itu sebagai pendidik harus mengawasi peserta didik dalam memanfaatkan teknologi. Keluarga sebagai orang terdekat peserta didik, juga berpartisipasi dalam mengawasi dan membimbing peserta didik dalam menggunakan teknologi sehingga peserta didik mampu memfilter dan membedakan mana hal yang baik dan buruk dari dampak teknologi itu sendiri.

\section{Konsep Dasar Pendidikan Karakter}

Konsep dasar pendidikan karakter tertuang dalam Permendikbud No 23 tentang Penumbuhan Budi Pekerti tahun 2015. Penumbuhan Budi Pekerti (PBP) bertujuan: 
1) Menjadikan sekolah sebagai taman belajar yang menyenangkan bagi siswa, guru, dan tenaga kependidikan,

2) Menumbuhkembangkan kebiasaan yang baik sebagai bentuk pendidikan karakter sejak di keluarga, sekolah dan masyarakat,

3) Menjadikan pendidikan sebagai gerakan yang melibatkan pemerintah, pemerintah daerah, masyarakat dan keluarga, dan/ atau

4) Menumbuhkembangkan lingkungan dan budaya belajar yang serasi antara keluarga, sekolah, dan masyarakat.

Karakter terbentuk dari kegiatan yang dilakukan secara berulang dan menjadi sebuah kebiasaan.Kebiasaan inilah yang menempel dan menjadi karakter seseorang.Penanaman dan pengembangan karakter di lingkungan sekolah menjadi tanggung jawab bersama bukan hanya guru namun juga kerjasama dari murid dan orangtua.Bagaimanapun juga perkembangan karakter di sekolah hanya menjadi ,suplemen "e bagi peserta didik.Sementara „makanan pokok" perkembangan karakter yang sebenarnya ialah di rumah.Dimana keluarga memiliki tanggung jawab besar dalam mendidik seorang anak di rumah.

\section{Prinsip Pendidikan Karakter}

Character Education Quality Standart merekomendasikan sebelas prinsip untuk mewujudkan karakter yang efektif, sebagai berikut:

1. Mempromosikan nilai-nilai dasar etika sebagai basis karakter.

2. Mengidentifikasikan karakter secara komperehensif supaya mencakup pemikiran, perasaan dan perilaku.

3. Menggunakan pendekatan yang tajam, proaktif dan efektif untuk membangun karakter.

4. Menciptakan komunitas sekolah yang memiliki kepedulian.

5. Memberi kesempatan kepada siswa untuk menunjukkan perilaku yang baik.

6. Memiliki cakupan terhadap kurikulum yang bermakna dan menantang yang menghargai semua siswa, membangun karakter mereka dan membantu mereka untuk sukses.

7. Mengusahakan tumbuhnya motivasi diri para siswa.

8. Melibatkan staf sekolah sebagai komunitas pembelajaran dan moral untuk berbagi tanggung jawab dalam pendidikan karakter dan untuk mematuhi nilainilai inti yang sama dalam membimbing pendidiakn peserta didik.

9. Menumbuhkan kebersamaam dalam kepemimpinan moral dan dukungan jangka panjang bagi inisiatif pendidikan karakter.

10. Melibatkan anggota keluarga dan masyarakat sebagai mitra dalam upaya pembangunan karakter. 
11. Mengevaluasi karakter sekolah, fungsi staf sekolah sebagai pendidik karakter, dan sejauh mana peserta didik memanifestasikan karakter yang baik.

Peran Pendidikan Dalam Penanaman Karakter

Penanaman karakter dalam perannya dalam bidang pendidikan adalah sebagai berikut:

1) Pembinaan watak, (jujur, cerdas, peduli, tangguh) merupakan tugas utama pendidika.

2) Mengubah kebiasaan buruk tahap demi tahap yang pada akhirnya menjadi bak. Dapat mengubah kebiasaan senang tetapi jelek yang pada akhirnya menjadi benci tetapi menjadi baik.

3) Karakter merupakan sifat yang teranam di dalam jiwa dan dengan sifat itu seseorang secara spontan dapat dengan mudah memancarkan sikap, tindakan dan perbuatan.

4) Karakter adalah sifat yang terwujud dalam kemampuan daya dorong dari dalam kelar untuk menampilkan perilaku terpuji dan mengandung kebajikan.

Penanaman-penanaman nilai karakter tersebut dapat diimplementasikan dan dijadikan budaya sekolah. Proses yang efektif untuk membangun budaya sekolah adalah dengan melibatkan dan mengajak semua pihak atau pemangku kepentingan untuk bersama-sama memberikan komitmennya. Banyak nilai yang dapat dan harus dibangun di sekolah, seperti nilai peduli dan kreatif, jujur, tanggung jawab, disiplin, sehat dan bersih, saling peduli antar sesama. Sekolah adalah laksana taman atau lahan yang subur tempat menyemaikan dan menanam benih-benih nilai tersebut. maka dari itu, pendidikan karakter di sekolah adalah tugas bersama.

\section{Pendidikan Karakter di Era Digital}

Zaman serba teknologi ini menjadikan anak telihat sangat pasif dan jarang untuk bersosialisasi di keluarga maupun masyarakat. Kebanyakan anak zaman sekarang lebih fokus untuk memperhatikan layar di depan matanya dibandingkan bermain dengan teman sebayanya. Sehingga tak jarang anak kehilangan waktu berharganya

bermain bersama keluarga, belajar, mengembangkan bakat atau bermain bersama temantemannya karena fokusnya sudah diambil alih oleh layar ponsel ataupun teknologi yang ada.Disini peran orangtua sangat penting dalam membimbing, memantau, serta mengatur waktu anak dari alat digital yang dipakai. Adapun yang harus dilakukan orang tua terhadap anak dalam pengasuhan digital atau digital parenting adalah sebagai berikut:

a. Meningkatkan dan memperbarui wawasan tentang internet dan gadget. Orang tua tidak bisa mengawasi anak-anak apabila orang tua gagap teknologi.

b. Jika di rumah ada internet, posisikan di ruang keluarga dan siapa yang dapat melihat apa yang dilakukan anak dalam mengakses internet.

c. Membatasi waktu pada anak dalam menggunakan gadget dan internet.

d. Memberikan pemahaman dan kesadaran bersama akan dampak negative dari internet atau gadget Secara tegas melarang sesegera mungkin jika ada yang tidak pantas ditonton 
f. Menjalin komunikasi yang terbuka dua arah dengan anak-anak.

Anak-anak era digital telah banyak dimanjakan dengan teknologi yang serba canggih, seperti mencari bahan pembelajaran melalui situs Google, permainan tradisional sudah banyak ditinggalkan. Ciri-ciri Generasi Digital adalah sebagai berikut:

1. Generasi digital ramai-ramai membuat akun di media sosial untuk membuktikan kepada dunia bahwa mereka ada.

2. Generasi digital cenderung lebih terbuka, blak-blakan, dan berfikit lebih agresif.

3. Generasi digital cenderung ingin memperoleh kebebasan. Mereka tidak suka diatur dan dikekang. Mereka ingin memegang kontrol dan internet menawarkan kebebasan berekspresi.

4. Generasi digital selalu mengakses dengan Google, Yahoo, atau situs lainnya. Kemampuan belajar mereka jauh lebih cepat karena segala informasi ada di ujung jari mereka.

Sebagai seorang pendidik dan seorang orang tua, harus menjadi panutan dan rolemodel yang baik untuk anak demi membentuk kepribadian dan karakter yang baik. Apalagi di era digital ini sangat mudah untuk menggali dan mendapatkan informasi di internet.Sebagai pendidik ataupun orang tua sudah seharusnya menjadi pengawas dan pembimbing yang baik untuk anak-anak dalam mendapatkan infromasi. Apalagi usia anak-anak sekolah dasar yang masih belum mampu membedakan dengan baik mana hal yang baik dan mana hal yang buruk. Dikahawatirkan, dengan teknologi yang ada, anak-anak justru terkena dampak negatif dari teknologi itu sendiri karena kurangnya pantauan pendidik maupun orangtua.

Dini (2018) menyebutkan dampak positif dan negative dari teknologi digital, sebagai berikut:

1. Dampak Positif

1) Sarana penyampaian informasi, informasi suatu kejadian secara cepat, tepat dan akurat

2) Mempermudah akses terhadap informasi baru, memperoleh informasi kapanpun dan dimanapun.

3) Media sosial, mempertemukan individu dengan orang yang baru, mempertemukan individu dengan teman lama yang jarang sekali bertemu, saran berbisnis.

4) Membantu dalam mencari informasi bahan pelajaran bagi peserta didik.

5) Media hiburan.

6) Sebagai eksistensi seseorang dalam media sosial. Mempermudah komunikasi meskipun dalam keadaan jarak yang jauh.

2. Dampak Negatif

1) Anak bersifat Individual, berkurangnya tingkat pertemuan langsung atau interksi antar sesama manusia.

2) Temperamen, kebiasaan bersosialisasi dengan media sosial, maka anak akan beranggapan bahwa dunia luar adalah ancaman.

3) Berita tanpa tanggung jawab, berita Hoax, Bulying.

4) Rentannya kesehatan mata, terutama mengalami rabun jauh atau rabun dekat.

5) Tak bisa menikmati hidup. Ketika menghadiri sebuah acara pesta, kita malah asik berfoto, tanpa menimati acara pesta dan musik. 
6) Radiasi alat hasil teknologi membahayakan kesehatan otak anak.

7) Maraknya kasus penipuan lewat sms, telepon dan internet.

8) Mudahnya mengakses video porno.

9) Anak lupa akan pekerjaan rumah yang ditugaskan oleh guru dan lupa melaksanakan ibadah, seperti sholat dan mengaji.

10) Anak menjadi sasaran kejahatan, seperti penculikan anak dan pemerkosaan anak.

Contoh kasus yang paling banyak dan marak terjadi adalah bullying dimana dampaknya sangat berpengaruh pada korban.Dampaknya bukan hanya jangka pendek melainkan jangka panjang bahkan bisa terbawa sampai korban melanjutkan pendidikan ke jenjang sekolah yang lebih tinggi.Dampak bullying sendiri membuat korban menjadi minder, tidak percaya diri, cenderung menutup diri dari lingkungan sosial, menyakiti diri sendiri atau paling parahnya lagi ialah memiliki hasrat untuk bunuh diri.

Selain bullying, situs pornografi merupakan salah satu dampak negative dari teknologi yang ada.Kemudahan dalam mengakses dan menyebarkan video secara digital ternyata masih banyak yang disalahgunakan.Apalagi, pemerintah sendiri tidak untuk membatasi akses situs pornografi yang ada di internet.Hal-hal seperti ini yang menjadikan banyaknya anak bangsa yang karakternya masih cenderung buruk. Maka dari itu pengawasan dari orangtua dan pendidik sangat diperlukan untuk memantau apa yang anak lakukan dengan gadgetnya demi berkembangnya karakter anak menjadi lebih baik. Lagipula, anak pada usia sekolah dasar memang seharusnya menggunakan waktunya untuk berkumpul keluarga, bermain bersama teman, bersosialisasi untuk mengasah keterampilan sosialnya dibandingkan menghabiskan waktu dengan gadgetnya hanya untuk bermain video game dan sejenisnya.

Peran Keluarga, Guru dan Masyarakat Dalam Pendidikan Karakter

a. Peran Keluarga dalam Pendidikan Karakter

Orang tua menjadi orang yang paling bertanggung jawab atas perkembangan karakter anak karena keluarga merupakan penyelenggara pendidikan paling utama dan pertama sebelum pendidikan pendamping lainnya.Orang tua juga turut berperan dalam perkembangan karakter anak di sekolah.Ada beberapa kegiatan yang bisa orang tua lakukan seperti, memantau perkembangan perilaku anak mereka melalui buku kegiatan siswa yang sudah disiapkan pihak sekolah, aktif mengikuti kegiatan rutin atau bergilir yang dilaksanakan pihak sekolah dalam pertemuan-pertemuan antara orang tua dengan wali kelas dan guru-guru kelas. Di era Digital saat ini anak-anak usia sekolah dasar tidak bisa lepas dari gadget bahkan menjadi sebuah kebutuhan. Gadget bagi mereka adalah teman setia. Kondisi seperti itu, orang tua perlu memperkenalkan kepada anak-anak mengenai situs pendidikan bila menggunakan gadget, seperti video-video animasi yang mengedukasi, sehingga anak tidak mudah bosan, atau games pendidikan yang mengasah kemampuan kognitif, video tata cara sholat, dan program-program belajar lainnya yang penting untuk diingat. Orang tua juga berperan mengawasi dan membatasi anak-anak dalam menggunakan ponsel, atur waktu kapan ia harus mengerjakan tugas sekolahnya, bersosialisasi dengan teman, bersosialisasi tengan keluarga, dan menggunakan ponsel atau gadget. 
b. Peran Guru dalam Budaya Karakter di Sekolah Guru mempersiapkan berbagai pilihan dan strategi untuk menanamkan setiap nilai-nilai, norma-norma dan kebiasaan-kebiasaan ke dalam mata pelajaran yang diampunya. Guru dapat memilih cara-cara tertentu dalam proses pembelajarannya, seperti menyampaikan berbagai kutipan yang berupa katakata mutiara atau peribahasa yang berkaitan dengan karakter, cerita pendek, diskusi kelompok, membuat karangan pendek dan sebagainya. Setiap sekolah hendaknya menentukan kegiatan khusus yang dapat mengikat para guru untuk melakukan kegiatan tersebut secara berkelanjutan. Berikut contoh penerapan keteladan pendidikan karakter di sekolah:

1. Guru secara sadar datang dan pulang tepat waktu sesuai jadwal kerja dan mengajar. hal ini bukan

hanya bentuk disiplin guru sebagai rolemodel siswa di sekolah namun juga sebagai bentuk komitmen dari kesepakatan yang sudah disetujui antara guru dengan pihak sekolah.

2. Sekolah memberikan penghargaan terhadap setiap keberhasilan, usaha, dan memberikan komitmennya, semua karyawan dan siswanya akan termotivasi untuk bekerja keras, inovatif, dan mendukung perubahan.

3. Sekolah juga memberikan program-program khusus bimbingan konseling pada siswa yang memiliki kesulitan belajar. Dengan adanya bimbingan dan usaha tersebut, siswa terbantu untuk memperbaiki cara belajar, mengembangkan potensinya secara maksimal dan belajar mengubah dirinya menjadi manusia yang lebih baik lagi.

4. Sekolah memberikan apresiasi pada saat upacara bendera pada hari senin, untuk guru,

karyawan dan siswa yang berprestasi. Cara yang dilakukan ini memotivasi setiap guru, karyawan dan siswa untuk meraih prestasi-prestasi tertentu.

5. Sekolah menerapkan makan bersama pada guru dan siswa pada saat jam istirahat. Dengan

begitu, akan menumbuhkan sifat kebersamaan dan kedekatan antara murid dengan guru.

\section{Peran Masyarakat dalam Pendidikan Karakter}

Sekolah bersama komite sekolah dan masyarakat secara bersama-sama menyusun suatu kegiatan yang dapat mendukung terwujudnya pembudayaan dan penanaman karakter yang baik bagi seluruh warga sekolah kegiatan yang dapat dilakukan antara lain seperti, melakukan gotong royong membersihkan tempat-tempat umum seperti masjid, sungai, dan lainnya. Masyarakat juga memainkan peran tak kalah pentingnya sebagai contoh atau model yang dapat menjadi pendorong keberhasilan para siswa dalam menerapkan nilai norma, dan kebiasaan-kebiasaan karakter yang baik.

\section{KESIMPULAN}

Karakter seseorang akan terbentuk bila aktivitas dilakukan berulang-ulang secara rutin hingga menjadi suatu kebiasaan, yang akhirnya tidak hanya menjadi suatu kebiasaan saja tetapi sudah menjadi suatu karakter. Maka dari itu, pendidikan karakter harus dilakukan sedini mungkin agar anak mampu menanamkan karakter yang baik sehingga mereka bisa membawanya hingga usia dewasa. Pendidikan karakter di sekolah dapat diterapkan pada semua mata pelajaran.Setiap mata pelajaran yang berkaitan denga normanorma perlu dikembangkan dan dikaitkan dengan kehidupan sehari-hari.Di era digital ini peran keluarga, guru dan masyarakat sekitar sangatlah penting dalam meningkatkan karakter calon penerus bangsa.Keluarga sebagai tempat utama dan pertama peserta didik menjalani kehidupan dan pendidikannya hendaklah mengawasi dan membimbing dengan 
penuh kasih sayang, tegas, dan cermat.Peran guru di sekolah bukan hanya mengajar tetapi juga mendidik. Peran guru sebagai rolemodel dalam pandangan anak sehingga guru akan menjadi patokan bagi sikap anak didik. Guru tidak hanya mengajarkan konsep karakter yang baik, tetapi bagaimana mengarahkan peserta didik untuk dapat mengimplementasikan pada kehidupam sehari-hari. Masyarakat sekitar juga berperan dalam mengawasi dan memotivasi perkembangan karakter peserta didik.

\section{DAFTAR PUSTAKA}

Daryanto, Darmiatun Suryatri. 2013.Implementasi Pendidikan Karakter di Sekolah. (Gava Media: Yogyakarta), 68.

Departemen Agama RI. 2000. Al-Qurean dan Terjemahnya. Jakarta: PT. Intermasa.

Departemen Pendidikan Nasional. 2003. Undang-Undang Republik Indonesia No. 20 Tahun 2003 Tentang Sistem Pendidikan Nasional. Jakarta: Depdiknas.

1. Dini Palupi Putri. (2018). Pendidikan Karakter Pada Anak Sekolah Dasar di Era Digital.AR-RIAYAH :Jurnal Pendidikan Dasar, 2, (1), 38-48.

2. Elmubarok, Z. (2008). Membumikan Pendidikan Nilai. Bandung: Alfabeta.

3. Lickonna.T. (1992).Education for Character, How Our Schools Can Teach Respect and Responsibility. New York: Bantam Books.

4. Muhammad Amran, Erma Suryani Suhabuddin, Muslimin. (2018). Peran Pendidikan Karakter di Sekolah Dasar. Makasar: Seminar Nasional Administrasi Pendidikan dan Manajemen Pendidikan Hotel Remcy Makasar, 255.

5. Peraturan Presiden No 87 Pasal 2 Tahun 2017, Penguatan Pendidikan Karakter, (http://ditjenpp.kemenkumham.go.id/arsip/ln/2017/ps87-2017.pdf), (diakses pada 9 Januari 2020).

6. Salman Hasibuan. (2015). Budaya Media dan Partisipasi Anak di Era digital, Proceeding of International Post-Graduate Conference. Surabaya:Prodi S2 Komunikasi Universitas AIRLANGGA Surabaya, 833.

7. Samani, M \& Hariyanto.(2013). Konsep dan Model Pendidikan Karakter. Bandung: PT. Remaja Rosdakarya.

8. Sukiman, dkk. (2016). Seri Pendidikan Orang Tua: Mendidik Anak di Era Digital. Jakarta: Kementerian Pendidikan dan Kebudayaan.

9. Yulia Palupi. Digital Parenting Sebagai Wahana Terapi untuk Menyeimbangkan Dunia Digital dengan Dunia Nyata Bagi Anak. (Yogyakarta: Seminar Nasional Universitas PGRI Yogyakarta, 2015), 49.

10. Arsyam m. (2020) pengaruh kemampuan supervisional kepala sekolah dan peran komite sekolah terhadap kenerja guru sma negri di kota makassar

11. Arsyam m, dan umar, k, (2020) manusia sebagai pendidik perspektif islam dan barat.

12. Arsyam m, jumliadi, m, H, dan alwi, a. M. S. (2020). Pembelajaran dirumah dalam lingkungan

keluarga di tengah pandemi covid 19.

13. Herianto, h, \& hamid, n (2020). Analisis proses berpikir kreatif dalam pemecahan masalah

geometri berdasarkan gaya kognitif reflektif dan imflusif siswa. Pedagogy: jurnal pendidikan

matematika 5,(2), 38-49.

14. Herianto, h. (2020) teknik menulis artikel konseptual. 
15. Herianto, h. (2019) PENERAPAN METODE ACCELERATED LEARNING FOR 21 st CENTURY DALAM MENINGKATKAN HASIL BELAJAR MATEMATIKA SISWA. Delta: jurnal ilmiah pendidikan matematika, 7(2), 37(50).

16. 22. Jusmiana, A., Herianto, H..,\& Awalia, R. (2020). Pengaruh penggunaan media Audio Visual Terhadap Hasil Belajar Matematika Siswa Smp Di Era Pandemi Covid19. Pedagogy:jurnal pendidikan matematiaka , 5(2), 1-11. 